University of Nebraska - Lincoln

DigitalCommons@University of Nebraska - Lincoln

USDA National Wildlife Research Center - Staff

Publications

U.S. Department of Agriculture: Animal and Plant Health Inspection Service

June 2007

The Introduction and Emergence of Wildlife Diseases in North America

Robert G. McLean

Follow this and additional works at: https://digitalcommons.unl.edu/icwdm_usdanwrc

Part of the Environmental Sciences Commons

McLean, Robert G., "The Introduction and Emergence of Wildlife Diseases in North America" (2007). USDA National Wildlife Research Center - Staff Publications. 710.

https://digitalcommons.unl.edu/icwdm_usdanwrc/710

This Article is brought to you for free and open access by the U.S. Department of Agriculture: Animal and Plant Health Inspection Service at DigitalCommons@University of Nebraska - Lincoln. It has been accepted for inclusion in USDA National Wildlife Research Center - Staff Publications by an authorized administrator of DigitalCommons@University of Nebraska - Lincoln. 


\title{
15 The Introduction and Emergence of Wildlife Diseases in North America
}

\author{
Robert G. McLean
}

\section{CONTENTS}

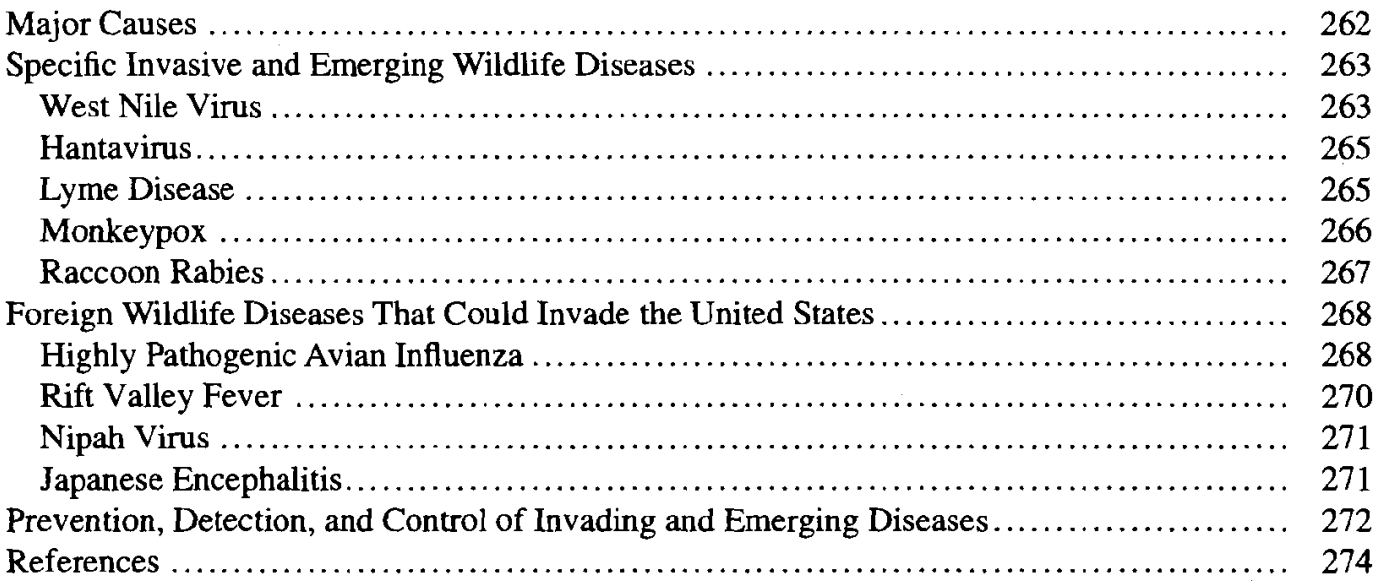

Following a period of success in controlling infectious diseases with new vaccines, global vaccination programs (smallpox and polio), antibiotics, and advanced treatments, especially in the United States during the 1960 s to the early 1980 s, an era of invading, emerging, and reemerging diseases began. These diseases accelerated through the 1990s and early 2000s, resulting in new disease threats and outbreaks with increased human health risks and huge economic impacts [e.g., AIDS, Lyme disease (LD), West Nile (WN) virus, and severe acute respiratory syndrome-associated coronavirus (SARS-CoV)]. Of the 175 new human emerging diseases, $75 \%$ were caused by zoonotic disease agents transmitted between wild or domestic animals and humans (Cleaveland et al. 2001), and these emerging pathogens were predominantly viruses (Woolhouse and Gowtage-Sequeria 2005); for example, Hantavirus, WN virus, Monkeypox, SARS-CoV, and Nipah virus. Many of the newly emerging pathogens have seriously impacted the global public health and animal health infectious disease infrastructure, and some pathogens had the threat of producing pandemics, such as SARS$\mathrm{CoV}$ and recently highly pathogenic avian influenza (HPAI) virus (Fauci et al. 2005). The causes and methods of dissemination of these invading and emerging diseases are as varied as the diseases themselves. Despite advances in medicine and technology, we have been unable to prevent their introduction, establishment, or spread. Recent developments in rapid detection and identification 
technology have greatly improved surveillance capabilities (Kuiken et al. 2003), but many of these diseases have wildlife as natural hosts and disseminators of the pathogens, and we have insufficient resources to effectively manage the diseases in wildlife populations. I discuss some of the major causes of invasive and emerging diseases and provide examples of wildlife diseases of public health and animal health importance that invaded or emerged in North America during the past few decades and some foreign animal diseases that threaten new invasions. I then discuss measures that are in place and those that could be improved to prevent, detect, and hopefully control these disease threats.

\section{MAJOR CAUSES}

The causes of the emergence, reemergence, and invasion of infectious diseases are varied and complex. Factors that are associated with and have contributed to emergence of pathogens include evolutionary changes in the pathogen (HPAI), changes in ecology of the host and pathogens (LD), and invasion of pathogens by movement of the infected host or vector species (WN virus) (Morse 1995; Wilson 1995; Lederberg 1998; Daszak et al. 2000; Cleaveland et al. 2001; Antia et al. 2003; Slingenbergh et al. 2004; Fauci et al. 2005; Gibbs 2005; Woolhouse and Gowtage-Sequeueria 2005). The frequency of new disease threats is increasing while the investment in public health and animal health infrastructure to deal with these challenges tries to keep up in the developed countries like the United States, but falls behind throughout the rest of the world.

One of the major causes of this increase of invasive and emerging diseases is unchecked human population growth. During the past 50 years, the world population increased more rapidly than ever before, and more rapidly than it will likely grow in the future. In 2000 , the world population had reached 6.1 billion, and this number could rise to more than 9 billion in the next 50 years (Lutz and Qiang 2002). This human population growth continuously puts an enormous demand on undeveloped land for housing, agriculture, and production of goods, creates further urbanization of natural environments, and concentrates human populations, making them more exposed to and at higher risk for transmission of certain diseases. This human population growth also promotes further encroachment into wilderness habitats that are the natural niches of insect vectors and wildlife hosts and their shared pathogens, making humans more likely to be infected with exotic viruses such as Ebola, jungle yellow fever, Nipah, and HIV. The expanding demand for wood and agricultural products promotes the destruction of more and more tropical and temperate forests and exposes forest and agriculture workers and their families to disease pathogens such as Ebola in Africa, yellow fever and arenaviruses in South America, and Nipah virus in Malaysia.

Another cause of invading and emerging diseases is the increased frequency and rapidity of international travel that can transport people, animals, animal products, and pathogens worldwide within 1-2 days, well within the incubation period of most diseases. Travel associated with ecotourism, business, and leisure can move an individual exposed to a pathogen from one continent to another, arriving with an infectious disease that can be transmitted before symptoms appear and introduce an exotic disease such as Nipah or Rift Valley Fever (RFV), both of which have wildlife reservoirs and can severely affect domestic livestock. Luckily, most introductions are not successful, but some pathogenic microbes introduced into new areas can survive the introduction, infect susceptible hosts, cause disease, become established, and emerge into a major disease of public health or animal health importance (Wilson 1995). Emerging diseases are also caused by the global wildlife trade that rapidly transports wildlife through major international routes, mostly through uncontrolled or illegal networks, and involves millions of birds, mammals, reptiles, amphibians, and fish every year (Karesh et al. 2005). The intermixing of wildlife species from many parts of the world in crowded livewildlife markets in China and other countries combined with close contact among domestic animals, such as poultry and pigs, and humans provides a great opportunity for disease transmission and the development of new emerging diseases such as SARS and HPAI strains. Once one of these diseases jumps to humans, then rapid international travel can disseminate the disease worldwide and cause 
major public health problems, resulting in enormous economic impact (SARS; Ksiazek et al. 2003). Legal trade of wildlife can also lead to emerging diseases. Wildlife hosts naturally infected in their native habitats where the disease does not cause clinical disease that are captured and transported to new environments or situations, again very rapidly, can transmit the disease to naïve wildlife hosts and cause disease and die-offs in these wild animals and expose associated humans (monkeypox).

Emergence of wildlife diseases can occur in wildlife populations when their natural sustaining habitats are destroyed or modified for human use, fragmented, or deteriorated (Friend et al. 2001). These negative ecological changes concentrate wildlife at high densities in inferior habitats, resulting in increased stress, reduced nutrition, and enhanced transmission of diseases. An important wetland region in central valley of California supported huge migratory and wintering waterbird populations, but $>90 \%$ of these natural wetlands were drained or converted to support human population increase. This loss of critical habitat forced these birds to shift south to the Salton Sea in southern California, which is a $974-\mathrm{km}^{2}$ lake in the desert, and is an agriculture drainage reservoir of poor habitat quality with salinity (44 ppt) exceeding that of the ocean. The Salton Sea had high fish production that supported large waterbird populations, but habitat deterioration led to massive fish die-offs followed by significant disease outbreaks in waterbirds, particularly pelicans, caused by an unusual form of botulism involving fish ( $\mathrm{Nol}$ et al. 2004).

\section{SPECIFIC INVASIVE AND EMERGING WILDLIFE DISEASES}

There have been a series of emerging and invasive wildlife diseases that affect humans and domestic animals during the past few decades. Some of these disease threats affected the entire North American continent and have become endemic, continuing to cause severe disease and mortality. A few of these diseases will be discussed in more detail (Table 15.1), including discussions about the reasons for the emergence and measures to control or prevent the disease (Table 15.2).

\section{West NiLe Virus}

The most spectacular invading and emergent disease during the past 20 years was the West Nile virus (Flavivirus, Flaviviridae, and WNV). This mosquito-borne virus made it to New York City, probably via an infected mosquito, bird, or human from the Middle East during the spring or early summer 1999 (Lanciotti et al. 1999), and quickly amplified in local bird populations (Eidson et al. 2001a). By autumn 1999, a small human epidemic occurred (CDC 1999a), and the virus distribution

\section{TABLE 15.1}

Examples of Invading, Emerging, and Re-emerging Wildlife Diseases of Public Health and Animal Health Importance in the United States

\begin{tabular}{|c|c|c|c|c|c|}
\hline Disease & $\begin{array}{l}\text { First year } \\
\text { reported in the } \\
\text { United States }\end{array}$ & Pathogen type & $\begin{array}{l}\text { Transmission } \\
\text { method }\end{array}$ & $\begin{array}{c}\text { Primary } \\
\text { vertebrate } \\
\text { host }\end{array}$ & $\begin{array}{c}\text { Origin of } \\
\text { disease agent }\end{array}$ \\
\hline Raccoon rabies & 1956 & Virus & Animal bite & Carnivores & United States \\
\hline Lyme disease & 1982 & Bacteria & Tick bite & Rodents & United States \\
\hline Hantavirus & 1993 & Virus & $\begin{array}{l}\text { Direct aerosol, animal } \\
\text { contact }\end{array}$ & Deer mice & United States \\
\hline West Nile virus & 1999 & Virus & Mosquito bite & Avian species & Middle East \\
\hline Monkeypox & 2003 & Virus & $\begin{array}{l}\text { Direct aerosol, animal } \\
\text { bite, or contact }\end{array}$ & Rodents & West Africa \\
\hline
\end{tabular}


TABLE 15.2

Reasons for the Emergence and Re-emergence of Wildlife Diseases of Public Health and Animal Health Importance in the United States

\begin{tabular}{|c|c|c|c|c|}
\hline Disease & First year & States started & States expanded & Reasons disease agent established/expanded \\
\hline Raccoon rabies & $1950 \mathrm{~s}$ & FL & 20 & $\begin{array}{l}\text { Slow gradual expansion of new strain northward } \\
\text { from Florida to four states by early } 1970 \text { s; } \\
\text { translocation north in } 1977 \text { and rapid expansion in } \\
\text { NE States in } 1980-90 \text { s; west to Ohio in } 1996 \text { and } \\
\text { north to Canada by } 1999\end{array}$ \\
\hline Lyme disease & 1982 & $\mathrm{CT}$ & 49 (reported) & $\begin{array}{l}\text { Fragmented forest and suburban habitats supported } \\
\text { high host and tick populations for expansion }\end{array}$ \\
\hline Hantavirus & 1993 & $\begin{array}{l}\mathrm{NM}, \mathrm{AZ}, \\
\mathrm{CO}, \text { and } \mathrm{UT}\end{array}$ & 30 & $\begin{array}{l}\text { Discovery of more infected locations - } \\
\text { prevention/education, reduced risks and cases }\end{array}$ \\
\hline West Nile virus & 1999 & NY & 48 & $\begin{array}{l}\text { Ideal weather and susceptible host and vector } \\
\text { populations to become established and virulence of } \\
\text { virus-strain produced broad host'vector range to } \\
\text { allow expansion to many new ecosystems in NA }\end{array}$ \\
\hline Monkeypox & 2003 & $\mathrm{TX}$ & (8) (eliminated) & $\begin{array}{l}\text { Rapid movement and mixing of infected rodents } \\
\text { with native rodents in animal facilities - did not } \\
\text { survive or become established }\end{array}$ \\
\hline
\end{tabular}

expanded outward from the introduction site in all directions to about a $160-\mathrm{km}$-diameter circle in three states surrounding New York City (Eidson et al. 2001b), as evidenced by WNV-positive dead birds. It became evident early that the WNV strain introduced was particularly virulent for native bird species and caused significant mortality, especially in Corvidae species (Bernard et al. 2001). This unique feature of mosquito-borne flaviviruses was utilized to detect and track the movement of WNV and became the primary tool for active surveillance by local and state public health departments for the first few years when only small numbers of human cases were occurring. This dead bird surveillance was accompanied by passive surveillance for human and equine cases and active testing of sentinel birds and mosquito collections in some states (CDC 2000).

The abundance of susceptible native avian species and optimum natural habitats for avian hosts and vector mosquitoes throughout NA supported the establishment and rapid expansion of WNV. The many millions of migratory birds moving south in the fall and north in the spring provided a means for the movement of the virus within NA and, subsequently, south to countries in the Caribbean and Central and South America. During the spread of WNV across the United States from 1999 to 2005 , it caused 19,655 human cases, 23,117 equine cases, and was responsible for 53,268 dead birds from 308 species reported from all 48 U.S. states to the public health surveillance network (Farnon 2006), with an estimated mortality in the millions of birds. Few other zoonotic diseases have been as successful in becoming established and in disseminating so rapidly and extensively as WNV. This successful invader is now endemic throughout most of NA, with WNV activity in 2005 reported in all 48 of the continental states of the United States, and its vinulence has apparently not changed during the past 7 years. It is currently invading South America (Mattar et al. 2005) and could spread throughout that continent in the near future.

The national WNV surveillance infrastructure that was quickly established in the eastern states and expanded throughout the United States included a national database (ArboNet), rapid testing and weekly reporting of surveillance data by states, a weekly updated national surveillance map displaying the continuing detection and spread of the virus (Marfin et al. 2001), and an annual surveillance conference to modify and improve the surveillance network was an excellent model for dealing with invasive and emerging diseases. Funding provided by the Centers for Disease Control 
and Prevention (CDC) through congressional appropriations to directly support surveillance and targeted research, and by the National Institutes of Health and CDC to fund research through grants, was effective in dealing with this massive disease threat. However, the public and media are now complacent about this disease that made big news for the past 6 years and the public may let down their guard to keep using the best protective measures, such as vaccination of their horses, eliminating mosquito breeding sites on their properties, and personal protection against mosquito bites, which could result in a resurgence of clinical disease.

\section{HANTAVIRUS}

Anovel hantavirus, Sin Nombre (SN) virus, Bunyaviridae, was discovered in 1993 during an outbreak of acute cardiopulmonary disease in humans living in a rural area in the Four Corners states of the southwestern United States (Nichol et al. 1993). This human epidemic followed a significant El Nino southern oscillation event resulting in an unusually wet winter and spring in this normally dry environment, and this increased precipitation promoted vegetation growth and subsequently produced very high populations of rodents during the summer months (Hjelle and Glass 2000). The high rodent populations amplified virus transmission and increased human contact with rodents, particularly following invasion and infestations of houses and outside buildings, and expanded exposure to infected rodents. Humans were exposed to the SN virus by the aerosol route through inhalation of virus-contaminated excreta from the natural reservoir host, the deer mouse (Peromyscus maniculatus). Deer mice are not affected by SN virus infections and excrete the virus in their urine, feces, and saliva, but a severe disease known as hantavirus pulmonary syndrome (HPS) with high mortality occurs in infected humans (Zeitz et al. 1995). This initially appeared to be a new emerging disease; however, it later became evident that HPS has been endemic in the United States for more than three decades with human cases recognized as early as 1959 (Frampton et al. 1995). The disease has been reported sporadically in humans throughout the range of the deer mouse in the Western and Midwestern states during the past 13 years following the initial outbreak, further indicating the broad endemicity of this virus and emphasizing the single host species and single virus relationships of this group of viruses. There have been 384 cases of HPS reported in the United States from 1993 to 2004. Other single host-virus combinations have been discovered throughout North and South America (Schmaljohn and Hjelle 1997). Control of the disease and prevention of human cases is targeted at reducing contact with infected rodents. Humans contract the disease mostly in and around their permanent or seasonal residences; therefore, the primary strategy for reducing exposure and infection with HPS is rodent prevention and control in and around the home (CDC 2006).

\section{LYME DISEASE}

Lyme disease is caused by the spirochete Borrelia burgdorferi and is transmitted through the bite of Ixodes spp. ticks. The natural history of the disease in the eastern United States includes rodents (primarily white-footed mice, Peromyscus leucopus, and eastern chipmunk, Tamias striatus) as the primary host species for the spirochete and for immature stages of the vector deer tick (Ixodes scapularis) and the white-tailed deer (Odocoileus virginianus) as the primary host maintaining the adult ticks (Lane et al. 1991; Steere 2001). LD was identified as a clinical syndrome of juvenile rheumatoid arthritis in children in Lyme, Connecticut, in 1976 (Steere et al. 1977) and the causative spirochete of LD was discovered in 1981 (Burgdorfer et al. 1982). Retrospective analysis of human cases found LD had occurred in Cape Cod in the 1960s and PCR analysis of museum specimens of ticks and rodents from Long Island found evidence of $B$. burgdorferi DNA from the late 1800s and early 1900s. However, few cases were reported before the national surveillance in the United States was started by the CDC in 1982 and LD was not designated as a nationally notifiable disease until 1991. LD began to emerge as the number of reported cases increased steadily since 1982 and LD distribution expanded in the northeastern and north central United States until it is now the most 
commonly reported arthropod-borne illness in the United States and Europe, with about 20,000 cases reported annually in the United States alone (CDC 2002).

The emergence of LD during the past 20 years was facilitated in the northeastern United States by the improving conditions for the ecology of LD. Before the disease emergence, this region was predominately farmland as a result of the clearing of the extensive woodlands during early colonization by Europeans. At the same time, deer populations were decimated by hunting. Farming declined in this region during the past $40-50$ years and farmland gradually reverted to meadows, shrubs, and secondary growth woodlands that provided food and shelter for increasing populations of deer and rodents. These habitat changes combined with a rapid expansion of human development in the region that converted the rural woodlands into wooded suburbs with grass yards and backyard woods where rodents and deer proliferated allowing the deer tick populations to thrive and expand. These suburban regions also have restrictions on hunting deer that have contributed to an even greater abundance of deer. This increase in the host populations for the spirochete and for the ticks enhanced transmission of the spirochete within the extensive suburbs and exposed the associated human populations to LD in their own yards and in recreational areas. The origin and progression of the LD region in the north-central states was different and likely started in the late 1970 s in central Wisconsin (Davis et al. 1984). The distribution of the tick and LD gradually expanded westward through western Wisconsin and into Minnesota in habitats conducive for the survival of the tick and the LD spirochete. This emergence was supported by the natural ecology of the region and represented a slow dispersal of the vector tick species and $\mathrm{LD}$ via the movement of its more mobile vertebrate hosts of deer and birds (McLean et al. 1993).

Because of the predominance of domicile transmission, prevention and control of LD has concentrated primarily on insecticide treatment of backyard habitats, acaricide treatment of mice to reduce tick abundance, or landscape changes to discourage use by rodents and deer. Advances have occurred with various control methods to reduce risk; nevertheless, the methods have generally been ineffective in significantly reducing transmission, although education for the use of personal protection measures may help. The number of reported human cases in the United States has remained at about 20,000 cases per year for the past few years.

\section{MONKEYPOX}

Monkeypox virus belongs to the Orthopoxvirus group of viruses that include variola (smallpox), vaccinia (used in smallpox vaccine), and cowpox viruses (Nalca et al. 2005). It is a rare viral disease in Africa that includes clinical signs and symptoms resembling those of smallpox, but which are usually milder. Humans are exposed to monkeypox from an infected animal through a bite, direct contact with fluids, or aerosols and person to person transmission can occur through the respiratory route, but less efficiently. Human outbreaks have been reported from areas in Central and West Africa with a fatality rate of $1-10 \%$ of cases. Wild mammal involvement with monkeypox virus in Africa is known mostly from serology and monkeys are thought to be incidental hosts similar to humans; whereas, multiple species of rodents are the likely reservoirs (Khodakevich et al. 1988). The only confirmed virus isolation was from a rope squirrel (Funisciuris anerythrus) from Zaire (Khodakevich et al. 1986).

Monkeypox was unknown in the western hemisphere until the virus was introduced into United States in a legal shipment of 762 African rodents, including some infected rodents, imported from Ghana, West Africa, by an exotic pet dealer in Texas (CDC 2003a). Most of these exotic mammals were subsequently shipped to an animal dealer in Iowa, although 178 of the African rodents could not be traced beyond the point of entry in Texas because records were not available. Some of the infected African rodents were then shipped from Iowa with other animals to a dealer in Illinois who housed these animals in the same room with 200 native prairie dogs (Cynomys sp.). Over half (110) of the prairie dogs that were exposed to infected African rodents were later shipped to animal dealers in multiple states and were sold to the public as pets before 15 became sick or died. Of the 
15 ill prairie dogs, 10 died rapidly, and 5 exhibited anorexia, wasting, sneezing, coughing, swollen eyelids, and ocular discharge. Infection and pathologic studies of infected prairie dogs showed the animals had bronchopneumonia, conjunctivitis, and tongue ulceration (Guarner et al. 2004). Active viral replication was observed in the lungs and tongue indicating that both respiratory and direct mucocutaneous exposure are potentially important routes of transmission of monkeypox virus between rodents and to humans. The remaining prairie dogs that could be located were destroyed. The high susceptibility of native prairie dogs to monkeypox was unexpected and was responsible for most of the human cases. Also, some of the African rodents became ill and died after arriving in the United States and were PCR positive for Monkeypox virus (CDC 2003b), including three dormice (Graphiurus sp.), two rope squirrels, and one Gambian giant pouched rat (Cricetomys sp.).

There were 71 reported cases of monkeypox in humans in the United States associated with the infected rodents, primarily as a result of contact with infected prairie dogs that had acquired monkeypox from diseased African rodents, and 35 cases were laboratory-confirmed in Illinois, Indiana, Kansas, Missouri, and Wisconsin (CDC 2003c; Sejvar et al. 2004; Kile et al. 2005). Most patients had mild, self-limited febrile rash illness; however, 18 were hospitalized (some for isolation purposes). Two of the hospitalized cases were children who required intensive care, one for severe monkeypox-associated encephalitis, and one with profound painful cervical and tonsillar adenopathy and diffuse pox lesions (Huhn et al. 2005). Both children recovered from their illness.

Non-native animal species, such as the African rodents, have become popular pets in the United States, but they can create serious public health and animal health problems when they introduce a new disease, such as monkeypox, to the native animal and human populations. The transportation, sale, or distribution of infected animals or the release of infected animals into the environment can result in the further spread of diseases to other animal species and to humans (CDC 2003c). Certain aspects of the importation and movement of exotic animals into and within the United States are under the jurisdiction and regulation of different federal and state agencies. As this disease situation progressed, it became clear that the state regulations were limited to their respective jurisdictions. Regulations differed among states in the types of animals and response actions that were covered and state rules expired on specific dates, all of which hampered efforts to manage and control the movement of the animals and the disease. Communicable diseases that are not confined by State borders, however, may require Federal action to help prevent their spread. The $\mathrm{CDC}$ and the Food and Drug Agency issued a joint order (DHHS 2003) to place a temporary embargo on the importation of all rodents from Africa and also banned the sale, movement, or release of prairie dogs into the environment to halt the dissemination of the monkeypox outbreak. Improvements in the regulation and control of the trade of wildlife exotic pets into and within the United States are needed to prevent future disease invasions. Human infections with monkeypox virus may be prevented by vaccination with vaccinia virus (the smallpox vaccine); even up to 14 days after exposure, but there are no licensed antiviral drugs available for post-exposure therapy (Nalca et al. 2005).

\section{RACCOON RABIES}

Rabies is an acute fatal encephalitis caused by neurotropic viruses in the genus Lyssavirus, family Rhabdoviridae. Rabies is a preventable disease of mammals that is transmitted primarily by the bite of a rabid animal. Preventable measures include pre-exposure vaccination and post-exposure treatment. Dog rabies was the predominant form of rabies from 1938 when national data on the incidence of rabies were first compiled until the 1950s. Rabies in wildlife was virtually unknown, but eventually became evident, and reporting began to increase as domestic animal rabies was drastically reduced and came under control through nationwide mandatory dog vaccination programs in the 1950s and then attention shifted to the underlying problem of wildlife rabies (McLean 1970). Rabies in raccoons (Procyon lotor) appeared in southern Florida in 1955-56 where it was unknown previously and raccoon rabies began to emerge as a new disease (Kappus et al. 1970). By the late 1960s and 
early 1970s, epizootics of raccoon rabies were occurring throughout Florida (Bigler et al. 1973), and raccoon rabies began to spread northward through Florida to Georgia (McLean 1971).

Although the existence of distinct genetic variants of rabies viruses was not documented until the late 1970s, the rabies virus in Florida raccoons was apparently a new variant, and raccoons began to emerge as an important new rabies host (Smith et al. 1984). Rabies in raccoons was spreading slowly northward to South Carolina, but its northward movement was assisted by humans with the translocation of infected raccoons from Florida to the Virginia/West Virginia border in 1977 for hunting purposes (Nettles et al. 1979). This introduction started a new focus of raccoon rabies that emerged rapidly and spread northward throughout the northeastern United States to Canada, southward to join the expanding front in South Carolina, and eventually westward to include all of the states east of the Appalachian Mountains and Ohio, Tennessee, and Alabama (Slate et al. 2005).

Small, targeted vaccination efforts to control raccoon rabies began in the mid-1990s utilizing a vaccinia-rabies glycoprotein recombinant (VRG) vaccine in a fishmeal bait (Hanlon et al. 1998). To expand the vaccination efforts, a coordinated oral rabies vaccination (ORV) program was implemented in 1998 by Wildlife Services, APHIS, USDA, to halt the westward spread of the raccoon rabies variant and to eventually eliminate this variant from the eastern United States (Slate et al. 2005). Millions of VRG vaccine baits are distributed, mostly by aircraft, each year in habitats that support raccoons to create immune buffer zones to stop the spread of raccoon rabies. In 2003, 4.23 million baits were dropped to target raccoons in states containing the Appalachian Ridge covering a 64,122$\mathrm{km}^{2}$ area in six states at a cost of about $\$ 96 / \mathrm{km}^{2}$ (Slate et al. 2005). Benefits from this vaccination program are in the expected savings in reduced costs for treatment of humans exposed to rabid or potentially rabid animals and reduced costs of public health programs for rabies detection, testing, prevention, and control in the United States, which has been estimated to be over $\$ 300$ million/year (Krebs et al. 1998). A similar vaccination program in South Texas contained the northward spread from Mexico of a canine strain of rabies adapted to coyotes (Canis latrans) and subsequently eliminated coyote rabies from the state (Fearneyhough et al. 1998). A vaccination buffer is maintained along the Texas-Mexico border to prevent the reentry of coyote rabies. Immediate goals of the National ORV Program are to prevent specific strains of the rabies virus in the raccoon, gray fox, and coyote from spreading to new, uninfected areas. The long-range goal is to eliminate these strains.

\section{FOREIGN WILDLIFE DISEASES THAT COULD INVADE THE UNITED STATES}

There are a number of wildlife diseases from throughout the globe that could invade NA under specific conditions, and many could become established. A few diseases will be presented as examples of the types of pathogens, the variety of vertebrate hosts involved, and the potential routes of entry into NA (Table 15.3).

\section{Highly Pathogenic Avian Influenza}

The most likely new invasive disease for NA is the HPAI strain of H5N1 subtype, type A virus. Aquatic birds, particularly Anseriformes (ducks, geese, and swans) and Charadriiformes (gulls, terns, and shorebirds or waders) are infected with a variety of subtypes of influenza A (AI) viruses and are likely the natural reservoirs (Krauss et al. 2004). Nearly all of the subtypes of AI viruses are endemic in and circulate in wild bird populations, predominantly in waterfowl species (Webster et al. 2006). Low-pathogenic avian influenza (LPAI) viruses have been isolated from more than 100 wild bird species and all of the AI virus subtypes have been detected in wild bird reservoirs and poultry (Olsen et al. 2006). Many strains of AI virus can infect a variety of domestic birds, such as chickens, turkeys, pheasants, quail, ducks, geese, and guinea fowl, and cause varying amounts of clinical illness. The pathogenicity of AI viruses are based on the severity of the disease they 
TABLE 15.3

Examples of Foreign Wildlife Diseases of Public Health and Animal Health Importance That Could Invade the United States

\begin{tabular}{|c|c|c|c|c|c|}
\hline Disease & $\begin{array}{c}\text { Method of } \\
\text { potential introduction }\end{array}$ & $\begin{array}{c}\text { Pathogen } \\
\text { type }\end{array}$ & $\begin{array}{l}\text { Transmission } \\
\text { method }\end{array}$ & $\begin{array}{c}\text { Primary } \\
\text { vertebrate hosts }\end{array}$ & $\begin{array}{l}\text { Origin of } \\
\text { pathogen }\end{array}$ \\
\hline $\begin{array}{l}\text { HP H5N1 } \\
\text { Asian avian } \\
\text { influenza }\end{array}$ & $\begin{array}{l}\text { Migratory waterfowl, } \\
\text { poultry, humans }\end{array}$ & Virus & $\begin{array}{l}\text { Direct/ } \\
\text { aerosol-ingestion }\end{array}$ & $\begin{array}{l}\text { Waterfowl, } \\
\text { poultry }\end{array}$ & SE Asia \\
\hline $\begin{array}{l}\text { Rift Valley } \\
\text { Fever }\end{array}$ & $\begin{array}{l}\text { Infected mosquito, } \\
\text { rodent import or } \\
\text { human }\end{array}$ & Virus & $\begin{array}{l}\text { Mosquito bite, } \\
\text { direct }\end{array}$ & $\begin{array}{l}\text { Rodents, sheep, } \\
\text { cattle }\end{array}$ & $\begin{array}{l}\text { Africa, } \\
\text { Arabian Peninsula }\end{array}$ \\
\hline $\begin{array}{l}\text { Japanese } \\
\text { encephalitis }\end{array}$ & $\begin{array}{l}\text { Infected mosquito or } \\
\text { human }\end{array}$ & Virus & Mosquito bite & Waterbirds, pigs & SE Asia \\
\hline Nipah virus & Infected bat or human & Virus & Direct & Fruit bats, pigs & Australia, Malaysia \\
\hline
\end{tabular}

cause, and most of these subtypes are LPAI forms that cause little or no disease although some strains are capable of mutating under field conditions or passage in chickens into HPAI viruses. HPAI viruses are an extremely infectious and fatal form of the disease that, once established, can spread rapidly among chickens and from flock to flock. Influenza viruses are unstable and specific mutations and evolution of these viruses occur with unpredictable frequency through the constant mingling of multiple subtypes in wild waterfowl populations and the frequent exchange of genetic material (Webster et al. 1992).

A HPAI virus strain, H5N1 subtype, evolved in China and was originally detected in 1996 when it caused mortality in wild geese at Qinghai Lake, China (Liu et al. 2005), which was unusual because AI subtypes do not usually cause disease in the natural hosts. This goose virus acquired other gene segments from quail and ducks and became the dominant genotype being transmitted in live poultry markets in Hong Kong in 1997 (Webster et al. 2006), causing extensive mortality in poultry and in 6 of 18 infected humans (de Jong et al. 1997). This genotype disappeared when all domestic poultry in Hong Kong were culled, but other reassortants from duck and goose reservoirs appeared with similar characteristics. These H5N1 viruses continued to develop until a single genotype in 2002 killed most of the wild and domestic waterfowl in Hong Kong (Sturm-Ramirez et al. 2004) and spread to humans. This 2002 genotype was the precursor of the $Z$ genotype that later became the dominant genotype that spread from China quickly south to Vietnam, Cambodia, Thailand, Laos, and Indonesia where it has caused numerous outbreaks in poultry and many human cases associated with sick or dead poultry. As of April 3, 2006, 165 human cases with 94 deaths (57\%) from HPAI H5N1 infections have been reported in China and Southeast Asia (WHO 2006). The H5N1 genotype subsequently spread west from SE Asia to Russia, Europe, the Middle East, and Africa causing outbreaks in poultry, some wild birds and scattered human cases (25 cases in four countries, with 13 deaths). Nearly all of the human cases were confirmed to have resulted directly from interactions with poultry.

The geographical spread of the virus was a result of a combination of factors, many of which can be attributed to humans. Local spread is likely achieved by human movement of poultry and poultry products to and from markets and commercial and backyard flocks, movement and interchange of fighting cocks, and local intermingling of domestic ducks (Webster et al. 2006). Longer-distance spread, particularly within a region, can be accomplished by commercial trade of poultry and poultry products, disseminating ducks and other aquatic birds that move seasonally through harvested rice fields, and migratory birds. The role of migratory birds in spreading AI viruses, especially LPAI, is well known and the Anseriformes and Charadriiformes are the major natural reservoirs for these 
viruses (Olsen et al. 2006). Millions of migratory birds move within and between large continents along major routes or flyways where bird populations connect with each other after sharing either common breeding areas, staging areas, or wintering grounds. Infected birds can transmit their viruses to susceptible birds that in turn can move the viruses to new areas. For example, migratory birds moving within the West Pacific and the East Asian-Australasian flyways overlap with each other and with birds in Alaska where some of them share common breeding areas with NA birds (Webster et al. 2006).

Serious concerns have been raised about the potential impact of HPAI H5N1 virus on domestic poultry, wild bird populations, and humans in the event that it is introduced into the United States. Potential routes of introduction of $\mathrm{H} 5 \mathrm{~N} 1$ into the United States could be through the illegal importation of domestic, pet, or wild birds (legal importation of birds is restricted or the birds must undergo 30-day quarantine), contaminated poultry products, infected human travelers (although there is no evidence yet of human to human sustainable transmission), bioterrorism event, or migration of infected wild birds through Alaska and the Pacific flyway or through eastern Canada and the Atlantic flyway. In response to these concerns, the U.S. government developed a "National Strategy for Pandemic Influenza" that outlines the responsibilities that local, state, and federal government departments and industry and individuals have in preparing for and responding to an influenza pandemic. Funding was provided to translate the national strategy into an Implementation Plan that provides guidance for the development of individual plans, identifies actions for Federal departments and agencies, sets clear expectations for local and state governments and for nongovernment entities, and provides guidance for individuals and families to prepare for a pandemic (http://www.pandemicflu.gov/plan/tab1.html). Three major components of the strategy are preparedness and communication, surveillance and detection, and response and containment.

The federal government's role in the surveillance and detection part of the "National Strategy for Pandernic Influenza" was to develop an interagency strategic plan for an early detection system for highly pathogenic H5N1 avian influenza in wild migratory birds (USDA 2006a). The plan outlines five major surveillance strategies for detecting H5N1: (1) investigation of morbidity/mortality events, (2) surveillance of live wild birds, (3) surveillance of hunter-killed birds, (4) sentinel species, and (5) environmental sampling. The National Wildlife Research Center was designated to conduct the environmental sampling strategy and will be testing fecal and water samples collected from high-risk waterfowl habitats across the United States. Surveillance will initially be focused in Alaska, where H5N1 is likely to be introduced from Asia, and secondarily on the Atlantic coast, where HPAI could be introduced with migratory birds that cross over the Atlantic Ocean from Europe to Canada and the eastern coast of the United States. Special attention will also be given to locations along major flyways, particularly the Pacific and Mississippi flyways, that migratory waterfowl use when moving south from Alaska during the fall and winter in the southern United States and farther south into the Caribbean and Latin America.

\section{Rift Valley Fever}

Rift Valley Fever (RVF) is a vector-transmitted, viral zoonoses of domestic livestock and other mammals in sub-Saharan Africa. The ecology of RFV is unique (Wilson 1994), because the virus can survive in arid grasslands where it persists in the eggs of multiple species of Aedes mosquitoes, the primary vectors and reservoirs of the virus, that hatch in natural depressions in the grasslands when they are flooded following periodic heavy rains (Davies et al. 1985). The adult mosquitoes emerge already infected and feed on nearby mammals, particularly domestic ungulates, and initiate local virus transmission. The cattle, sheep, and goats that become infected circulate high amounts of virus and infect mosquitoes and other arthropods. This circulation of the virus amplifies transmission that leads to periodic epizootics in domestic animals, causing abortions and death in susceptible animals. Human infections occur through vector transmission, aerosols, or direct contact with infected animals, and epidemics of about 27,000 cases with 170 deaths have been reported in Kenya, East Africa 
(Woods et al. 2002). The RVF virus escaped from the African Continent for the first time in 2000 through the transport of infected livestock to Saudi Arabia and Yemen where it caused an epizootic in livestock and a subsequent human epidemic (Madani et al. 2003). Other means by which this virus could be transported out of Africa and into the United States are through infected wild mammals (rodents in the pet trade), humans as airline passengers, infected adult mosquitoes, or infected Aedes mosquito eggs transported on a passenger plane or ship. Once the virus arrives there are numerous Aedes and other mosquito species in the United States that are competent vectors, abundant wildlife species, especially rodents, as natural reservoirs (Gora et al. 2000), and enormous populations of susceptible livestock throughout the country that would serve as amplifying hosts. This virus could easily become established as WNV did and would have a huge impact on the sheep and cattle industry.

\section{NiPAH VIRUS}

Nipah virus is an emerging zoonotic virus in the new genus Henipavirus within the family Paramyxoviridae that also includes Hendra virus. Nipah is a highly pathogenic virus that emerged from fruit bats in Malaysia in 1998 largely due to shifts in livestock production and alterations to reservoir host habitat. The virus caused outbreaks of fatal disease in domestic pigs and humans with substantial economic loss to the local pig industry (CDC 1999b). The disease in pigs showed respiratory and neurological signs that spread to humans causing severe febrile encephalitis resulting in death in 40-75\% of cases (Chua et al. 1999). Fruit bats in the genus Pteropus are the natural reservoir host of Nipah virus (Johara et al. 2001) and these bat populations have been substantially reduced in Southeast Asia during the past two decades because of extensive deforestation of their natural habitats and climatic effects (Chua et al. 2002). In 1997/98, slash-and-burn of forests led to agricultural expansion and intensification in the modified areas, including the development of piggeries located in cultivated fruit orchards. The deforestation also reduced the availability of fruiting forest trees for forging fruit bats forcing them to encroach upon cultivated fruit orchards. These changes allowed the juxtaposition of the natural bat host with a highly susceptible domestic pig in the fruit orchards that allowed transmission of a novel virus from its reservoir host to the domestic pig and subsequently to the farmers attending the pigs. The virus distribution expanded to Australia and Singapore and caused five subsequent outbreaks between 2001 and 2005 in Bangladesh. During these outbreaks, the virus appears to have been transmitted directly from bats to humans and person-to-person transmission possibly occurred, suggesting an increased public health risk (Epstein et al. 2006).

Fruit bats became a popular exotic animal introduced into the pet trade in the United States in the early 1990s, but the threat of introducing a pathogenic virus resulted in a complete embargo on importation. This regulatory action reduced the possibility of an introduction of Nipah-virusinfected bats similar to the introduction of monkeypox with infected rodents, but with a much more lethal virus. However, some risks of introduction still exist from illegal importation of bats, movement of infected pigs or pig products, infected human travelers, and bioterrorism (Lam 2003). The introduction of Nipah virus into NA could have severe consequences for domestic and wild pigs and associated humans.

\section{JAPANESE ENCEPHALITIS}

Japanese encephalitis (JE) is a common but serious human disease in 16 countries of eastern and southern Asia and is the leading cause of viral encephalitis in these countries with 30,000-50,000 cases reported annually. Case-fatality rates vary from 0.3 to $60 \%$ (Endy and Nisalak 2002). Severe clinical disease and death from $\mathrm{JE}$ is age related, with most cases occurring in the very young and elderly. The majority of cases are mild infections, but severe infections can progress from acute encephalitis with high fever, disorientation, tremors, convulsions (especially in infants), spastic paralysis, coma, and death. Japanese encephalitis is a mosquito-borne virus (Flavivirus, Flaviviridae) 
closely related to WNV and St. Louis encephalitis virus that has birds as the natural hosts. Ricefield-breeding mosquitoes (Culex tritaeniorhynchus group) are the primary enzootic vector, and waterbirds (herons and egrets) are the major avian amplifying host species in SE Asia. Blackcrowned night herons (Nycticorax nycticorax), egrets (Egretta sp.) and European starlings (Sturnus vulgaris) were shown experimentally to be competent hosts to infect Culex mosquitoes (Soman et al. 1977). Periodic epidemics occur when the virus is brought into peridomestic environments by birds and mosquito bridge vectors are infected by feeding on the birds and transmitting the virus to domestic pigs that serve as additional amplifying hosts for other mosquitoes to pass the virus to humans (Burke and Leake 1988). Some countries that have had major epidemics are controlling the disease through human vaccination programs. The virus has spread recently to northem Australia, probably by migratory birds (Hanna et al. 1996). The risks and routes of introduction of JE virus into the United States are similar to what they were for WNV. If JE virus is introduced, it could become as easily established and disseminated as WNV because of the availability of abundant avian hosts and competent mosquito vectors, but possibly more confined to areas around bodies of water that contain more waterbirds. Many regions in the southern states also have large populations of free-ranging feral pigs mixed among the wetland habitats containing many species of waterbirds that could support intense amplification and outbreaks of the disease. There may be some cross protection of infections between the closely related JE and WNV viruses (Tesh et al. 2002).

\section{PREVENTION, DETECTION, AND CONTROL OF INVADING AND EMERGING DISEASES}

There are other foreign animal diseases (FAD), besides monkeypox and WN viruses, that could be introduced with infected wild animals [rodents (RVF, Lassa Fever), birds (JE, HPAI), bats (Nipah), primates (yellow fever)], domestic animals (Foot and Mouth Disease, African swine fever, Venezuelan equine encephalitis, RVF), or humans (Ebola, Lassa fever, and Nipah). Other emerging zoonotic diseases need to be monitored such as bovine TB, leptospirosis, tularemia, and Escherichia coli $0157: \mathrm{H} 7$ and other pathogenic bacteria. Theoretically, the most effective prevention and control methods are obviously to prevent the introduction or emergence of wildlife diseases of public health or animal health importance rather than attempting to control them after they have become a problem. Prevention of introduction is a daunting task because of the many sources and routes of introduction into the United States, and early detection is one of the keys to prevention and rapid control or containment. Research advances have helped to manage and mitigate some of the effects of invasive and emerging infectious diseases such as improved worldwide surveillance, improved diagnostics methods, and the development of new vaccines and antiviral agents (Kuiken et al. 2003). A number of preventative methods are in place, although many can be improved, intensified, or broadened. A variety of FADs have been identified throughout the world that could potentially be introduced, and information is available and has been obtained on many diseases; however, a more systematic and thorough collection of detailed and comprehensive information on the natural hosts, vectors, and disease manifestations in native hosts and in potential hosts in the United States needs to be completed. To this end, experimental studies of susceptibility of native wildlife species to FADs could be conducted before the potential disease invasion and provide valuable planning information to improve detection and surveillance (Tesh et al. 2004). There are many information sources that can be used, such as

World Organization for Animal Health (Organization International Epizootics, OIE)

World Health Organization (WHO)

Pan American Health Organization (PAHO)

Food and Agriculture Organization (FAO) 
Individual governments and their agencies such as

\author{
United States Department of Agriculture (USDA) \\ Centers for Disease Control and Prevention (CDC) \\ Department of Homeland Security (DHS) \\ Department of Defense (DOD) \\ Department of Interior (DOI) in the United States \\ Universities \\ Nongovernment organizations
}

Potential routes of FAD entry into the United States must be carefully analyzed and all possible scenarios examined. This information is needed to identify gaps in regulatory authority for specific wildlife or vector species and holes in observations and testing procedures during importation and quarantine that could miss another wildlife disease entry like monkeypox. Certain aspects of the importation and movement of exotic animals into and within the United States are under the jurisdiction and regulation of different federal and state agencies. Increased coordination and communication among agencies would improve chances of detecting an invasive disease. Changes in restrictions on importation of high-risk animals or products and increases in quarantine time periods and species to be quarantined are available and are used when necessary. However, screening of incoming wild animals and animal products at ports of entry for potential infectious diseases are inadequate. Technological advances have made rapid, sensitive, and accurate detection equipment and procedures available (Kuiken et al. 2003), but they must be deployed to test high-risk wildlife species at first entry for specific diseases.

In addition to the established ports of entry to prevent introduction, a nationwide passive and active surveillance system of wildlife diseases and nationwide information network for disease reporting and evaluation are needed for early detection and reporting of those wildlife diseases of concern that successfully became established before we are surprised by a disease outbreak in wildlife, humans, or domestic animals. Beyond the initial detection of a disease pathogen, a plan to integrate nationwide resources for a rapid and adequate response to contain, mitigate, and control high-risk disease outbreaks in wildlife is essential; for example, a discovery-to-control continuum process (Murphy 1998). The National Strategy for Pandemic Influenza plan for the early detection of HPAI H5NI virus in the United States and for the implementation of a nationwide response is a good example of being prepared for the potential invasion of a high impact disease.

The real challenge is the management and elimination of the diseases once they have been introduced or emerged. The immediate containment and eradication of the WNV introduction into New York City, United States, in 1999 would have saved thousands of human and equine cases, millions of birds that died, and hundreds of millions of dollars to deal with this exotic disease that got a foothold in a small area and subsequently spread throughout the western hemisphere. The transmission cycles of most zoonotic, wildlife diseases are known and include disease agents and hosts for diseases transmitted directly between hosts like rabies and include a vector(s) and possibly multiple hosts for diseases transmitted indirectly between hosts such as WNV. The components of transmission cycles that are theoretically the most critical and vulnerable to manipulation (weakest links) are the ones targeted for intervention to interrupt or stop transmission. Control of direct transmitted diseases like wildlife rabies is focused on reducing contact between an infected and a susceptible animal by either population suppression to reduce the probability of contact or vaccination of susceptible animals. Vaccinated animals are dead-ends for the virus and thus limit transmission and allow the disease to burn itself out (Slate et al. 2005). The weakest link in most vector-transmitted diseases is the vector and not the vertebrate host and vector control is accomplished best through an integrated pest management approach in community wide programs (CDC 2000). Vector-transmitted diseases of mammals such as LD are easier to attack, because the vertebrate host species and tick 
vectors are relatively sedentary and thus transmission is more predictable. Mosquito-transmitted viral diseases of birds such as WNV are more difficult to predict where virus transmission is or will be occurring, because the avian host species are not sedentary and the diseases are spatially and temporally dynamic. This uncertainty makes it problematical in controlling mosquito populations to reduce transmission; therefore, disease control methods utilize chemical and biological compounds to reduce larval production through early control in historical problem-breeding sites and population reduction of adult mosquitoes over larger areas when active transmission is elevated (Moore et al. 1993). The availability and use of equine vaccines have greatly reduced the number of equine cases from some high impact, mosquito-borne diseases such as WNV and eastern equine encephalitis (USDA 2006b) although cases still occur in areas where the vaccines are not used regularly or effectively.

\section{REFERENCES}

Antia, R., .R. R. Regoes, J. C. Koella, and C. T. Bergstrom. 2003. The role of evolution in the emergence of infectious diseases. Nature 426:658.

Bernard, K. A., J. G. Maffei, S. A. Jones, E. B. Kauffman, G. D. Ebel, A. P. Dupuis II, K. A. Ngo, D. C. Nicholas, D. M. Young, P.- Y. Shi, V. L. Kulasekera, M. Eidson, D. J. White, W. B. Stone, NY State West Nile Virus Surveillance Team, and L. D. Kramer. 2001. West Nile virus infection in birds and mosquitoes, New York State, 2000. Emerg. Infect. Dis. 7:679.

Bigler, W. J., R. G McLean, and H. A. Trevino. 1973. Epizootiologic aspects of raccoon rabies in Florida. Am. J. Epidemiol. 98:326.

Burgdorfer, W., A. G. Barbour, S. F. Hayes, J. L. Benach, E. Grunwaldt, and J. P. Davis. 1982. Lyme disease - a tick-borne spirochetosis?, Science 216:1317.

Burke, D. S., and C. J. Leake. 1988. Japanese encephalitis, in The Arboviruses: Epidemiology and Ecology, T. P. Monath (ed.), vol. 3. Boca Raton: CRC Press, p. 63.

CDC, Centers for Disease Control and Prevention. 1999a. Outbreak of West Nile-like viral encephalitis - New York, 1999. Morb. Mortal. Wkly Rep. 48:845.

CDC, Centers for Disease Control and Prevention. 1999b. Outbreak of Hendra-like virus - Malaysia and Singapore, 1998-1999. Morb. Mortal. Wkly Rep. 48:265.

CDC, Centers for Disease Control and Prevention. 2000. Guidelines for Surveillance, Prevention, and Control of West Nile virus infection - United States. Morb. Mortal. Wkly Rep. 49:25.

CDC, Centers for Disease Control and Prevention. 2002. Lyme disease: United States. Morb. Mortal. Wkly Rep. 51:29.

CDC, Centers for Disease Control and Prevention. 2003a. Multistate outbreak of monkeypox - Illinois, Indiana, and Wisconsin, 2003. Morb. Mortal. Wkly Rep. 52:537

CDC, Centers for Disease Control and Prevention. 2003b. Update: multistate outbreak of monkeypox - Illinois, Indiana, Kansas, Missouri, Ohio, and Wisconsin, 2003. Morb. Mort. Wkly Rep. 52:616.

CDC, Centers for Disease Control and Prevention. 2003c. Update: multistate outbreak of monkeypox - Illinois, Indiana, Kansas, Missouri, Ohio, and Wisconsin, 2003. Morb. Mort. Wkly Rep. 52:642.

CDC, Centers for Disease Control and Prevention. 2006. Prevent rodent infestations, All about Hantavirus, http://www.cdc.gov/rodents/prevent_rodents/index.htm.

Chua, K. B., K. J. Goh, K. T. Wong, A. Kamarulzaman, P. S. Tan, T. G. Ksiazek, S. R. Zaki, G. Paul, S. K. Lam, and C. T. Tan. 1999. Fatal encephalitis due to Nipah virus among pig-farmers in Malaysia. Lancet 354:1257.

Chua, K. B., B. H. Chua, and C. W. Wang. 2002. Anthropogenic deforestation, El Nino and the emergence of Nipah virus in Malaysia. Malays. J. Pathol. 24:15.

Cleaveland, S., M. K. Laurenson, and L. H. Taylor. 2001. Diseases of humans and their domestic mammals: pathogen characteristics, host range and the risk of emergence. Trans. R. Soc. Lond. B. Biol. Sci. 356:991.

Daszak, P., A. A. Cunningham, and A. D. Hyatt. 2000. Emerging infectious diseases of wildlife - threats to biodiversity and human heaith. Science 287:443. 
Davies, F. G., K. J. Linthicum, and A. D. James. 1985. Rainfall and epizootic Rift Valley fever. Bull. World Health Organ. 63:941.

Davis, J. P., W. L. Schell, T. E. Amundson, M. S. Godsey, A. Spielman, W. Burgdorfer, A. G. Barbour, M. LaVenture, and R. A. Kaslow. 1984. Lyme disease in Wisconsin: epidemiologic, clinical, serologic, and entomologic findings. Yale J. Biol. Med. 57:685.

de Jong, J. C., E. C. Class, A. D. Osterhaus, R. G. Webster, and W. L. Lim. 1997. A pandemic warning? Nature 389:554.

DHHS, Department of Health and Human Services. 2003. Control of Communicable Diseases; Restrictions on African Rodents, Prairie Dogs, and Certain Other Animals, Doc 03-2755. Federal Register 68:62353.

Eidson, M., N. Komar, F. Sorhage, R. Nelson, T. Talbot, F. Mostashari, R. McLean, and West Nile Virus Avian Mortality Surveillance Group. 2001a. Crow deaths as a sentinel surveillance system for West Nile virus in the North-eastern United States, 1999. Emerg. Infect. Dis. 7:615.

Eidson, M., L. Kramer, W. Stone, Y. Hagiwara, K. Schmit, and West Nile Virus Avian Mortality Surveillance Group. $2001 \mathrm{~b}$. Dead hird surveillance as an early warning system for West Nile virus. Emerg. Infect. Dis. 7:631.

Endy, T. P., and A. Nisalak. 2002. Japanese Encephalitis Virus: Ecology and epidemiology, in Japanese encephalitis and West Nile viruses. Current Topics in Microbiology and lmmunology, J. S. Mackenzie, A. D. T. Barrett, and V. Deubel (eds) Vol. 267. Berlin: Springer-Verlag, p. 11.

Epstein, J. H., H. E. Field, S. Luby, J. R. Pulliam, and P. Daszak. 2006. Nipah virus: impact, origins, and causes of emergence. Curr. Infect. Dis. Rep. 8:59.

Farnon, E. 2006. Summary of West Nile Virus Activity, United States 2005. Seventh National Conference on West Nile Virus in the United States. Centers for Disease Control and Prevention, http://www.cdc.gov/ncidod/dvbid/westnile/conf/February_2006.htm.

Fauci, A. S., N. A. Touchette, and G. K. Folkers. 2005. Emerging infectious diseases: A 10-year perspective from the National Institute of Allergy and lnfectious Diseases. Emerg. Infect. Dis. 11:519.

Fearneyhough, M. G., P. J. Wilson, K. A. Clark, D. R. Smith, D. H. Johnston, B. N. Hicks, and G. M. Moore. 1998. Results of an oral rabies vaccination program for coyotes. J. Am. Vet. Med. Assoc. 212:498.

Frampton, J. W., S. Lanser, and C. R. Nichols. 1995. Sin Nombre virus infection in 1959. Lancet 346:781.

Friend, M., R. G. McLean, and F. J. Dein. 2001. Disease emergence in birds: challenges for the twenty-first century. Auk 118:290.

Gibbs, E. P. J. 2005. Emerging zoonotic epidemics in the interconnected global community. Vet. Rec. 157:673.

Gora, D., T. Yaya, T. Jocelyn, F. Didier, D. Maoulouth, S. Amadou, T. D. Ruel, and J. P. Gonzalez. 2000. The potential role of rodents in the enzootic cycle of Rift Valley fever in Senegal. Microbes Infect. 2:343.

Guamer, J., B. J. Johnson, C. D. Paddock, W. J. Shieh, C. S. Goldsmith, M. G. Reynolds, I. K. Damon, R. L. Regnery, S. R. Zaki: Veterniary Monkeypox Virus Working Group. 2004. Monkeypox transmission and pathogenesis in prairie dogs. Emerg. Infec. Dis. 10:426.

Hanlon, C. A., M. Niezgoda, A. N. Hamir, C. Schumacher, H. Koprowski, and C. E. Rupprecht. 1998. First North American field release of a vaccinia-rabies glycoprotein recombinant vinus. J. Wildl. Dis. 34:228.

Hanna, J. N., S. A. Ritchie, D. A. Phillips, J. Shield, M. C. Bailey, J. S. Mackenzie, M. Poidinger, B. J. McCall, and P. J. Mills. 1996. An outbreak of Japanese encephalitis in the Torres Strait, Australia, 1995. Med. J. Aust. 165:256.

Hjelle, B., and G. E. Glass. 2000. Outbreak of hantavirus infection in the four corners region of the United States in the wake of the 1997-1998 El Nino - southern oscillation. J. Infect. Dis. 181:1569.

Huhn, G. D., A. M. Bauer, K. Yorita, M. B. Graham, J. Sejvar, A. Likos, I. K. Damon, M. G. Reynolds, and M. J. Kuehnert. 2005. Clinical characteristics of human monkeypox, and risk factors for severe disease. Clin. Infect. Dis. 41:1742.

Johara, M. Y., H. Field, A. M. Rashdi, C. Morrissy, B. van der Heide, P. Rota, A. bin Adzhar, J. White, P. Daniels, A. Jamaluddin, and T. Ksiazek. 2001. Nipah virus infection in bats (order Chiroptera) in peninsular Malaysia. Emerg. Infect. Dis. 7:439.

Kappus, K. D., W. J. Bigler; R. G. McLean, and H. A. Trevino. 1970. The raccoon, an emerging rabies host. J. Wildl. Dis. 6:507.

Karesh, W. B., R. A. Cook, E. L. Bennett, and J. Newcomb. 2005. Wildlife trade and global disease emergence. Emerg. Infect. Dis. 11:1000. 
Khodakevich, L., Z. Jezek, and K. Kinzanzka. 1986. Isolation of monkeypox virus from wild squirrel infected in nature. Lancet 1:98.

Khodakevich, L., Z. Jezek, and D. Messinger. 1988. Monkeypox virus: ecology and public health significance. Bull. World. Health Organ. 66:747.

Kile, J. C., A. T. Fleischauer, B. Beard, M. J. Kuehnert, R. S. Kanwal, P. Pontones, H. J. Messersmith, R. Teclaw, K. L. Karem, Z. H. Braden, I. Damon, A. S. Khan, and M. Fischer. 2005. Transmission of monkeypox among persons exposed to infected prairie dogs in Indiana in 2003. Arch. Pediatr. Adolesc. Med. 159:1022.

Krauss, S., D. Walker, S. P. Pryor, L. Niles, L. Chenghong, V. W. Hinshaw, and R. G. Webster. 2004. Influenza A viruses of migrating wild aquatic birds in North America. Vector-Borne Zoonotic Dis. 4:177.

Krebs, J. W., S. C. Long-Martin, and J. E. Childs. 1998. Causes, costs, and estimates of rabies postexposure prophylaxis treatments in the United States. J. Public Health Manage. Pract. 4:56.

Ksiazek, T. G, D. Erdman, C. S. Goldsmith, S. R. Zaki, T. Peret, S. Emery, S. Tong, C. Urbani, J. A. Comer, W. Lim, P. E. Rollin, S. F. Dowell, A. E. Ling, C. D. Humphrey, W. J. Shieh, J. Guamer, C. D. Paddock, P. Rota, B. Fields, J. DeRisi, J. Y. Yang, N. Cox, J. M. Hughes, J. W. LeDuc, W. J. Bellini, L. J. Anderson; SARS Working Group. 2003. A novel coronavirus associated with severe acute respiratory syndrome. N. Engl. J. Med. 348:1967.

Kuiken, T., R. Fouchier, G. Rimelzwann, and A. Osterhaus. 2003. Emerging viral infectious in a rapidly changing world. Curr. Opin. Biotech. 14:641.

Lam, S. K. 2003. Nipah virus - a potential agent of bioterrorism? Antiviral Res. 57:113.

Lanciotti, R. S., J. T. Roehrig, V. Deubel, J. Smith, M. Parker, K. Steele, B. Crise, K. E. Volpe, M. B. Crabtree, J. H. Scherret, R. A. Hall, J. S. MacKenzie, C. B. Cropp, B. Panigrahy, E. Ostlund, B. Schmitt, M. Malkinson, C. Banet, J. Weissman, N. Komar, H. M. Savage, W. Stone, T. McNamara, and D. J. Gubler. 1999. Origin of the West Nile virus responsible for an outbreak of encephalitis in the northeastern United States. Science 286:2333.

Lane, R. S., J. Piesman, and W. Burgdorfer. 1991. Lyme borreliosis: relation of its causative agents to its vector and hosts in North America and Europe. Annu. Rev. Entomol. 36:587.

Lederberg, J. 1998. Emerging infections: An evolutionary perspective. Emerg. Infect. Dis. 4:366.

Liu, J., H. Xiao, F. Lei, Q. Zhu, K. Qin, X. W. Zhang, X. L. Zhang, D. Zhao, G. Wang, Y. Feng, J. Ma, W. Liu, J. Wang, and G. F. Gao. 2005. Highly pathogenic H5N1 influenza virus infection in migratory birds. Science 309:1206.

Lutz, W., and R. Qiang. 2002. Determinants of human population growth. Philos. Trans. R. Soc. Lond. B. Biol. Sci. 357:1197.

Madani, T. A., Y. Y. Al-Mazrou, M. H. Al-Jeffri, A. A. Mishkhas, A. M. Al-Rabeah, A. M. Tukistani, M. O. Al-Sayed, A. A. Abodahish, A. S. Khan, T. G. Ksiazek, and O. Shobokshi. 2003. Rift Valley fever epidemic in Saudi Arabia: epidemiological, clinical, and laboratory characteristics. Clin. Infect. Dis. 37:1084.

Marfin A. A., L. R. Peterson, M. Eidson, J. Miller, J. Hadler, C. Farello, B. Werner, G L. Campbell, M. Layton, P. Smith, E. Bresnitz, M. Cartter, J. Scaletta, G Obiri, M. Bunning, R. C. Craven, J. T. Roehrig, K. G. Julian, S. R. Hinten, D. J. Gubler, and the ArboNET Cooperative Surveillance Group. 2001. Widespread West Nile Virus Activity, Eastern United States, 2000. Emerg. Infect. Dis. 7:730.

Mattar, S., E. Edwards, J. Laguado, M. Gonzalez, J. Alvarez, and N. Komar. 2005. West Nile virus antibodies in Columbian horses. Emerg. Infect. Dis. 11:1497.

McLean, R. G 1970. Wildlife rabies in the United States: recent history and current concepts. J. Wildl. Dis. 6:229

McLean, R. G. 1971. Raccoon rabies in the southeastern United States. J. Infect. Dis. 123:680.

McLean, R. G, S. R. Ubico, C. A. Hughes, S. M. Engstrom, and S. M. Johnson. 1993. Isolation and characterization of Borrelia burgdorferi from blood of a bird captured in the Saint Croix River Valley. J. Clin. Microbiol. 31:2038.

Moore, C. G., R. G. McLean, C. J. Mitchell, R. S. Nasci, T. F. Tsai, C. H. Calisher, A. A. Marfin, P. S. Moore, and D. J. Gubler. 1993. Guidelines for arbovirus surveillance programs in the United States. Fort Collins: Centers for Disease Control and Prevention, 83 pp.

Morse, S. S. 1995. Factors in the emergence of infectious diseases. Emerg. Infect. Dis. 1:7.

Murphy, F. A. 1998. Emerging Zoonoses. Emerg. Infect. Dis. 4:429. 
Nalca, A., A. W. Rimoin, S. Bavari, and C. S. Whitehouse. 2005. Reemergence of Monkeypox: prevalence, diagnostics, and countermeasures. Clin. Infect. Dis. 41:1765.

Nettles, W. F., J. H. Shaddock, R. K. Sikes, and C. R. Reyes. 1979. Rabies in translocated raccoons. Am. J. Public Health 69:601.

Nichol, S. T., C. F. Spiropoulou, S. Morzunov, P. E. Rollin, T. G. Ksiazek, H. Feldmann, A. Sanchez, J. Childs, S. Zaki, and C. J. Peters. 1993. Genetic identification of a hantavirus associated with an outbreak of acute respiratory illness. Science 262:914.

Nol, P., T. E. Rocke, K. Gross, and T. M. Yuill. 2004. Prevalence of neurotoxic Clostridium botulinum type $\mathrm{C}$ in the gastrointestinal tracts of tilapia (Oreochromis mossambicus) in the Salton Sea. J. Wildl. Dis. 40414.

Olsen, B., V. J. Munster, A. Wallensten, J. Waldenstrom, A. D. Osterhaus, and R. A. Fouchier. 2006. Global patterns of influenza A virus in wild birds. Science 312:384.

Schmaljohn, C., and B. Hjelle. 1997. Hantavinuses: a global disease problem. Emerg. Infect. Dis. 3:95.

Sejvar, J. J., Y. Chowdary, M. Schomogyi, J. Stevens, J. Patel, K. Karem, M. Fischer, M. J. Kuehnert, S. R. Zaki, C. D. Paddock, J. Guamer, W. J. Shieh, J. L. Patton, N. Bernard, Y. Li, V. S. Olson, R. L. Kline, V. N. Loparev, D. S. Schmid, B. Beard, R. R. Regnery, and I. K. Damon. 2004. Human Monkeypox infection: a family cluster in the Midwestern United States. J. Infect. Dis. 190:1833.

Slate, D., C. E. Rupprecht, J. A. Rooney, D. Donovan, D. H. Lein, and R. B. Chipman. 2005. Status of oral rabies vaccination in wild camivores in the United States. Virus Res. 111:68.

Slingenbergh, J., M. Gilbert, K. I. de Balogh, and W. Wint. 2004. Ecological sources of zoonotic diseases. Rev. Sci. Tech. Off. Int. Epiz. 23:467.

Smith, J. S., J. W. Sumner, L. F. Roumillat, G. M. Baer, and W. G. Winkler. 1984. Antigenic characteristics of isolates associated with a new epizootic of raccoon rabies in the United States J. Infect. Dis. 149:769.

Soman, R. S., F. M. Rodrigues, S. N. Guttikar, and P. Y. Guru. 1977. Experimental viraemia and transmission of Japanese encephalitis virus by mosquitoes and ardeid birds. Ind. J. Med. Res. 66:709.

Steere, A. C. 2001. Lyme disease. N. Engl. J. Med. 345:115.

Steere, A. C., S. E. Malawista, D. R. Snydman, R. E. Shope, W. A. Andiman, M. R. Ross, and F. M. Steele. 1977. Lyme arthritis: an epidemic of oligoarticular arthritis in children and adults in three Connecticut communities. Arthritis Rheum. 20:7.

Sturm-Ramirez, K. M., T. Ellis, B. Bousfield, L. Bissett, K. Dyrting, J. E. Rehg, L. Poon, Y. Guan, M. Peiris, and R. B. Webster. 2004. Reemerging H5N1 influenza viruses in Hong Kong in 2002 are highly pathogenic to ducks. J. Virol. 78:4892.

Tesh, R. B., A. P. Travassos da Rosa, H. Guzman, T. P. Araujo, and S. Y. Xiao. 2002. Immunization with heterologous flaviviruses protective against fatal West Nile encephalitis. Emerg. Infect. Dis. 8:245.

Tesh R. B., D. M. Watts, E. Sbrana, M. Siirin, V. L. Popov, and S. Y. Xiao. 2004. Experimental infection of ground squirrels (Spermophilus tridecemlineatus) with monkeypox virus. Emerg. Infect. Dis. 10:1563.

WHO, World Health Organization website. 2006. Avian Influenza, http://www.who.int/csr/disease/ avian_influenza.html

USDA, United States Department of Agriculture. 2006a. Wild Bird Plan: An early detection system for highly pathogenic H5N1 avian influenza in wild migratory birds: U.S. Interagency Strategic Plan. News Release No. 0094.06. Web: http://www.usda.gov

USDA, United States Department of Agriculture. 2006b. West Nile virus, http:// www.aphis.usda.gov//pa/pubs/ fsheet_faq_notice/fs_ahwnv.html

Webster, R. G., W. J. Bean, O. T. Gorman, T. M. Chambers, and Y. Kawaoka. 1992. Evolution and ecology of influenza A viruses, Microbiol. Rev. 56:152.

Webster, R. G. M. Peiris, H. Chen, and Y. Guan. 2006. H5H1 outbreaks and enzootic influenza. J. Infect. Dis. $12: 3$.

Wilson M. E., Travel and the emergence of infectious diseases. 1995. Emerg. Infect. Dis. 1:39.

Wilson, M. L. 1994. Rift Valley fever ecology and the epidemiology of disease emergence. Ann. N. Y. Acad. Sci. 740:169.

Woods C. W., A. M. Karpati, T. Grein, N. McCarthy, P. Gaturuku, E. Muchiri, L. Dunster, A. Henderson, A. S. Khan, R. Swanepoel, I. Bonmarin, L. Martin, P. Mann, B. L. Smoak, M. Ryan, T. G. Ksiazek, R. R. Arthur, A. Ndikuyeze, N. N. Agata, C. J. Peters: World Health Organization Hemorrhagic Fever Task Force. 2002. An Outbreak of Rift Valley Fever in Northeastern Kenya, 1997-98. Emerg. Infect. Dis, 8:138. 
Woolhouse, M. E. J., and S. Gowtage-Sequeria. 2005. Host range and emerging and re-emerging pathogens, Emerg. Infect. Dis. 11:1842.

Zeitz, P. S., J. C. Butler, J. E. Cheek, M. C. Samuel, J. E. Childs, L. A. Shands, R. E. Voorhees, J. Sarisky, P.E. Rollin, T. G. Ksiazek, L. Chapman, S. E. Reef, K. K. Komatsu, C. Dalton, J. W. Krebs, G. O. Maupin, K. Gage, C. M. Sewell, R. F. Brelman, and C. J. Peters. 1995. A case-control study of hantavirus pulmonary syndrome during an outbreak in the southwestern United States. J. Infect. Dis. 171:864. 


\title{
WildLIFE SCIENCE \\ LINKING ECOLOGICAL THEORY AND MANAGEMENT APPLICATIONS
}

\author{
EDITED BY \\ TIMOThy E. Fulbright AND DAVID G. HewitT
}

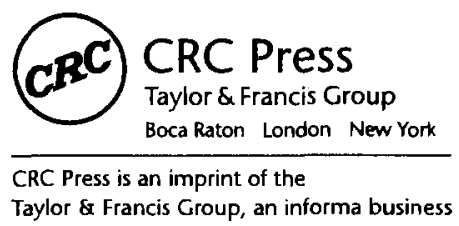


CRC Press

Taylor \& Francis Group

6000 Broken Sound Parkway NW, Suite 300

Boca Raton, FL 33487-2742

(C) 2008 by Taylor \& Francis Group, LLC

CRC Press is an imprint of Taylor \& Francis Group, an Informa business

No claim to original U.S. Government works

Printed in the United States of America on acid-free paper

10987654321

International Standard Book Number-10: 0-8493-7487-1 (Hardcover)

International Standard Book Number-13: 978-0-8493-7487-6 (Hardcover)

This book contains information obtained from authentic and highly regarded sources. Reprinted material is quoted with permission, and sources are indicated. A wide variety of references are listed. Reasonable efforts have been made to publish reliable data and information, but the author and the publisher cannot assume responsibility for the validity of all materials or for the consequences of their use.

No part of this book may be reprinted, reproduced, transmitted, or utilized in any form by any electronic, mechanical, or other means, now known or hereafter invented, including photocopying, microfilming, and recording, or in any information storage or retrieval system, without written permission from the publishers.

For permission to photocopy or use material electronically from this work, please access www.copyright.com (http:// www.copyright.com/) or contact the Copyright Clearance Center, Inc. (CCC) 222 Rosewood Drive, Danvers, MA 01923 978-750-8400. CCC is a not-for-profit organization that provides licenses and registration for a variety of users. For organizations that have been granted a photocopy license by the CCC, a separate system of payment has been arranged.

Trademark Notice: Product or corporate names may be trademarks or registered trademarks, and are used only for identification and explanation without intent to infringe.

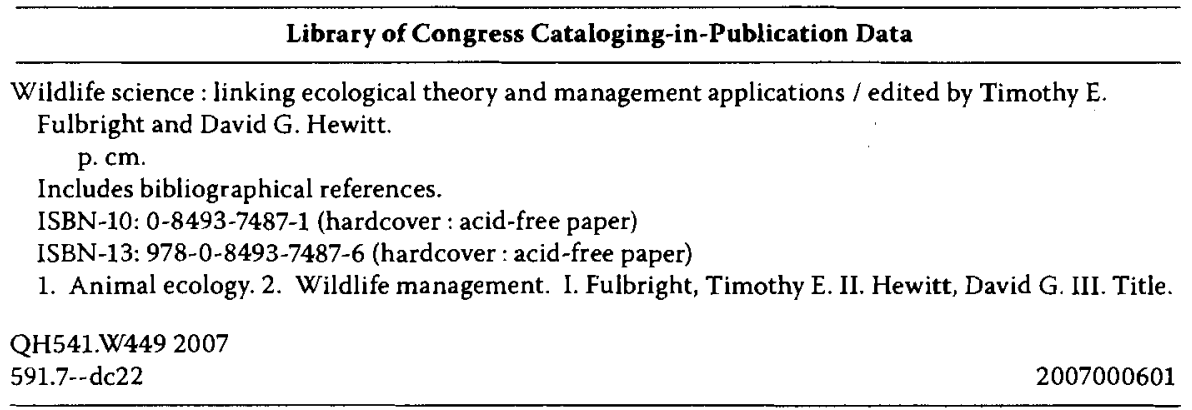

Visit the Taylor \& Francis Web site at

http://www.taylorandfrancis.com

and the CRC Press Web site at

http://www.crcpress.com 